\title{
Konziliární psychiatrie
}

\section{MUDr. Michal Vodička}

Psychiatrické oddělení Nemocnice České Budějovice, a.s.

Konziliární psychiatrie se zabývá diagnostikou a léčbou duševních onemocnění u somaticky nemocných pacientů. Duševní stav zapříčiněný psychiatrickým nebo somatickým onemocněním je v řadě př́padů obtížné zhodnotit nejen pro psychiatry, ale i pro somatické lékaře, kteři mohou bagatelizovat nebo opominout příznaky duševního onemocnění. Nedostatečná léčba duševních onemocnění u somaticky nemocných pacientů zvyšuje morbiditu a mortalitu pacientů.

Klíčová slova: somatizace, deprese, delirium, suicidium.

\section{Liaison psychiatry}

Liaison psychiatry specializes in diagnosis and treatment of mental disorders in patients with somatic pathology. In many cases it is difficult to assess, whether mental disease is due to somatic or mental disease not only for psychiatrists, but also for somatic doctors, who may play down or disregard symptoms of mental disease. Insufficient treatment of mental disorders in somatic ill patients increase morbidity and mortality of patients.

Key words: somatization, depression, delirium, suicide.

Úvod

Konziliární psychiatrie se zabývá diagnostikou a léčbou duševních onemocnění u somaticky nemocných pacientů. Při vyšetření pacienta musí psychiatrický konziliář znát nejen psychopatologii, ale i somatické choroby s jejich projevy v kontextu duševního onemocnění. Vždy je třeba zvažovat biopsychosociální model, podle kterého biologické, psychické a sociální 
faktory ovlivňuji vnímání a chování pacienta, a tedy rovněž i pocit nemoci či zdraví (1). Biomedicínská teorie předpokládá, že nemoc vzniká v důsledku tělesné patologie a duševní symptomy nesouvisí s tělesným onemocněním. Somatičtí lékaři se snaží určit a léčit somatickou patologii. Symptomy jsou pro ně pouze vodítkem k identifikaci nemoci, proto mají sklon popisovat pacienty na základě patologie, a ne na základě symptomů (např. pacient netrpí slabostí a nechutenstvím, ale má tumor) (2). Pokud se ale nenalezne tělesná príčina, která by přiměřeně vysvětlila obtíže pacienta, mohou somatičtí lékaři přisoudit aktuální stav pacienta psychické príčině. $V$ důsledku toho může dojít k opomenutí somatického onemocnění, ke zhoršení celkového stavu pacienta a ve vážnějších prípadech k úmrtí.

\section{Důvody psychiatrického konzilia}

Prevalence pacientů na somatickém oddělení je odlišná od struktury pacientů, kteř́ jsou hospitalizováni na psychiatrii nebo kteří jsou ambulantně léčeni psychiatry. V primární ambulantní péči se nejčastěji setkáváme s depresí, úzkostí, somatoformními poruchami, abúzem či závislostí na alkoholu (3). Na akutních somatických odděleních převažují akutní organické psychiatrické poruchy, zejména deliria. Funkční psychózy, jako je schizofrenie či schizoafektivní poruchy, jsou na somatických odděleních relativně vzácné (4). K nejčastějším důvodům, proč somatické oddělení požaduje konziliární vyšetření, patř̌:

\section{Somatoformní poruchy}

Tělesné př́iznaky nevysvětlitelné onemocněním se často nazývají funkční somatické př́znaky. V primární péči je přibližně $25 \%$ všech nových vyšetření v důsledku funkčních somatických symptomů (4). U hospitalizovaných pacientů patří funkční somatické symptomy k nejčastějším dưvodům hos- pitalizace na základě doporučení praktického lékaře. Somatické symptomy u 1/3 všech pacientů přijatých na gastroenterologii, neurologii a kardiologii jsou při propuštění diagnostikovány jako funkční (4). Somatizaci neboli př́tomnost somatických symptomů bez prokazatelných organických patologických změn Ize rozdělit na tzv. pravou a funkční. U pravé somatizace se jedná o somatický projev duševního onemocnění, nejčastěji deprese nebo úzkosti, a předpokládá se, že léčba základního duševního onemocnění povede ke zmírnění funkčních somatických symptomů (5). Funkční somatizace zahrnuje somatoformní poruchy. Více než 1/3 pacientů se somatoformními poruchami má komorbidní úzkostnou či depresivní poruchu (6).

\section{Gastrointestinální poruchy}

Syndrom dráždivého tračníku je charakterizován chronickou nevysvětlitelnou abdominální bolestí nebo potížemi spojenými s průjmem, zácpou nebo obojím (7). Klíčovou vlastností je intestinální hyperalgezie - nadměrně bolestivé reakce z pochodů ve střevě. U tohoto onemocnění je často př́tomna komorbidita s dalšími psychiatrickými poruchami, zejména s úzkostnými a afektivními poruchami (8). Až 1/3 pacientů se syndromem dráždivého tračníku má komorbidní posttraumatickou stresovou poruchu (9). Sexuální zneužívání je prediktivní faktor pro vznik syndromu dráždivého tračníku.

\section{Plicní a kardiovaskulární poruchy}

U pacientů s nedostatečně kompenzovaným astmatem hrají úzkostné poruchy významnou roli, zejména panická porucha, generalizovaná úzkostná porucha a specifické fobie (9).

Chronický stres, deprese a úzkost jsou rizikovými faktory vzniku kardiovaskulárních onemocnění a komplikují zotavení z akutní kardiální přihody. 
Deprese zvyšuje morbiditu a mortalitu v období po infarktu myokardu, nestabilní angině pectoris a po operaci bypassu koronární arterie. Deprese a úzkostné poruchy zvyšují riziko rozvoje kardiovaskulárních onemocnění, jako je infarkt myokardu, angina pectoris a hypertenze $(9,10)$.

\section{Maligní onemocnění}

U maligních onemocnění je vysoká komorbidita s depresí a s úzkostnými poruchami s prevalencí 10-30\% (9). Z úzkostných poruch jsou časté specifické fobie, panická porucha, generalizovaná úzkostná porucha, porucha přizpůsobení a posttraumatická stresová porucha.

\section{Bolest}

Bolest patří k nejčastějším chorobným příznakưm. Je to komplexní a subjektivní vjem určený senzorickými, psychickými a sociálními faktory. Bolest je nezbytný adaptivní pochod, který brání dalšímu poškození a umožňuje zotavení. Pokud se bolest stane chronickou, ztrácí své adaptivní vlastnosti. S chronickou bolestí je výrazně komorbidní depresivní porucha (11). Strach a úzkost velmi přispívají k prožitku chronické bolesti. Pacienti v primární péči se somatickými potížemi (např. bolest hlavy, břicha, svalů) mají vysokou míru depresivních a úzkostných symptomů (12). U pacientů s chronickými bolestmi páteře, bolestmi u revmatoidní artritidy, fibromyalgie a migrény je velká míra úzkostných poruch (9). U pacientů s bolestí na hrudi a negativním kardiálním nálezem je značná komorbidita zejména panické a depresivní poruchy (13). Psychiatrická symptomatika může být u bolesti jak primární, např. deprese může vést ke zvýšené senzitivitě k bolestivým symptomům, tak sekundární, kdy chronická bolest vede k rozvoji depresivních či úzkostných symptomů.

\section{Neobvyklé chování v nemoci}

Pacienti často popírají nebo potvrzují řadu symptomů, které vedou bud'k př́lišnému vyšetřování, nebo naopak k nediagnostikování závažného onemocnění. Toto chování lze označit jako neobvyklé chování v nemoci, což je kvantifikace sociologického konceptu "chování v nemoci", které popisuje chování a sociální roli nemocného (14). Jedná se o kognitivní, percepční a behaviorální aspekty reakce jedince na nemoc. Často bývá spojené s depresivními, úzkostnými a somatoformními poruchami, kdy pacient vnímá symptomy základního onemocnění výrazněji. Motivace k tomuto chování může být vědomá i nevědomá a obojí může být směřováno jak k popření choroby (např. riziko ztráty zaměstnání v př́padě nemoci či anosognozie u psychotického onemocnění), tak k jejímu potvrzení (faktitivní porucha, somatoformní poruchy) (4).

\section{Delirium}

Delirium patři k nejčastější diagnóze na somatických odděleních. Až 1/5 pacientů během pobytu v nemocnici prodělá delirium, na JIP je to až $87 \%$ pacientů (15). Delirium je třeba odlišit zejména od demence vzhledem k podobným přiznakům a časté komorbiditě. Některé studie popisují, že až 89\% př́padů demence u pacientů nad 65 let je komplikováno deliriem (16).

\section{Diagnóza a diferenciální diagnóza}

Typické vlastnosti deliria, tj. náhlý vznik, kolísavý průběh spolu s poruchou vědomí a pozornosti, u Alzheimerovy demence chybí a hlavním př́znakem jsou poruchy paměti. Odlišení deliria od demence s Lewyho tělísky je velmi obtížné vzhledem k podobné symptomatice, tj. prítomnost poruch pozornosti, zrakových halucinací a kolísání závažnosti příznaků, 
avšak senzitivita na antipsychotika, autonomní dysfunkce a systematizované bludy jsou u deliria vzácné (17).

Test MMSE umožňuje odhalit př́tomnost kognitivního deficitu, ale není schopen odlišit delirium od demence. Vhodnějšími nástroji pro zjištění deliria jsou CAM-ICU (the Confusion Assessment Method for the Intensive Care Unit) a ICDSC (Intensive Care Delirium Screening Checklist) (18).

Náhlá změna duševního stavu by měla vést k předpokladu deliria, dokud se neukáže jiná př́čina. Hypoaktivní delirium je často zaměněno za depresi (19). I když některé př́znaky depresivní epizody se vyskytují i u deliria (např. psychomotorické zpomalení, poruchy spánku, podrážděnost, myšlenky na smrt), je vznik symptomů u depresivní epizody méně rychlý, poruchy nálady jsou stabilnější a typicky dominují klinickému obrazu. Delirium rovněž napodobuje symptomy úzkostných poruch a kolísavý průběh může vést k mylné domněnce, že se jedná např. o panickou poruchu (20). Podáním benzodiazepinů u somatického deliria ve snaze zmírnit úzkost u předpokládané úzkostné poruchy může vést ke zhoršení symptomů deliria. Především u mladých jedinců je třeba odlišit delirium od funkčních psychóz, zejména schizofrenie. Na rozdíl od schizofrenie jsou halucinace u deliria častěji zrakové a občas čichové, taktilní nebo gustatorní. U schizofrenie není výrazný kognitivní deficit, halucinace jsou zejména sluchové, bludy jsou komplexnější a pozornost není tak výrazně narušena jako u deliria (18).

\section{Etiologie}

Etiologie deliria je rozsáhlá a multifaktoriální. Obecně je jakékoliv somatické onemocnění, které vede k funkčním či strukturálním změnám
CNS, rizikové k rozvoji deliria. Problematikou se podrobněji zabývá kniha Konzilární psychiatrie (21). K př́činám deliria patří infekce, dehydratace, hypoxie, metabolické encefalopatie (např. kardiální selhání), akutní vaskulární poruchy (infarkt myokardu, plicní embolie), endokrinopatie, poruchy minerálové rovnováhy, zvýšená hladina kortizolu, patologie CNS (cévní mozková príhoda, krvácení), trauma (úraz či operace), exogenní vlivy (vliv medikace - zejména léky s anticholinergním účinkem, opiáty a benzodiazepiny, dále intoxikace a syndrom z odnětí psychoaktivních látek). K deliriu může přispívat spánková deprivace, nedostatečně kontrolovaná bolest, prítomnost kognitivní poruchy a vysoký či nízký věk pacienta (19). Delirium může být způsobeno více etiologickými činiteli a zároveň může být př́tomna komorbidita s dalšími duševními poruchami, které nelze odlišit, dokud není zaléčen delirantní stav. Např́klad pacient se závislostí na alkoholu prijiatý na traumatologické oddělení po traumatickém poranění mozku. U pacienta se rozvine delirantní stav. Jeho etiologie může být v důsledku syndromu z odnětí alkoholu, může být v důsledku Wernickeovy encefalopatie, nebo v důsledku vlastního traumatického postižení mozku. Rovněž může být v důsledku jaterní encefalopatie. Nelze vyloučit ani centrální pontinní myelinolýzu, minerálovou nerovnováhu, dehydrataci, infekci (např. pneumonii). Při postižení kritických struktur mozku se zde může podílet i endokrinní etiologie (např. diabetes insipidus). Dále zde může být etiologie epileptogenní. Z vzácnějších onemocnění může být u pacienta prítomna např. Wilsonova choroba, kde je jaterní postižení časté, neurologická symptomatika nemusí být patrná a k častým psychiatrickým symptomům patří osobnostní změny s dezinhibovaným chováním s rizikem abúzu alkoholu a drog. A samozřejmě pacient může trpět i jinými somatickými chorobami bez prímé souvislosti s úrazem či závislostí na 
alkoholu (např. srdeční selhání) a jinými duševními chorobami (např. depresí). Kromě toho samotná intoxikace alkoholem zhoršuje prüběh léčby poranění mozku a může zhoršovat průběh somatického deliria $(22,23)$.

\section{Delirium u dětí}

Děti jsou velmi citlivé k rozvoji deliria, ale často u nich nebývá diagnostikováno. Celková anestezie a horečka vyvolá delirium u dětí častěji než u dospělých (24). Nejčastější etiologií deliria u dětí jsou infekce, vliv léků a trauma. Diferenciálně diagnosticky je třeba u dětí odlišit poruchy chování, depresi, schizofrenii a bipolární poruchu.

\section{Organické duševní poruchy}

Kromě deliria mohou somatické choroby vyvolat další duševní poruchy, které jsou často nazývané organické. V MKN 10 spadají do kategorie F06.x.

\section{Minerálové poruchy}

Minerálové poruchy jsou u somaticky nemocných pacientů běžné. Vždy je třeba léčit prričinu minerálové poruchy, například pankreatitidu či malabsorbční syndromy. Diagnostické obtiže může činit hypokalcemie bez ohledu na př́činu. Její projevy mohou napodobit demenci, afektivní poruchy, úzkostné poruchy či schizofrenii (22). Př́znaky hypofosfatemie mohou být podobné symptomům Wernickeovy encefalopatie a zejména u pacientů se závislostí na alkoholu mưže dojít k záměně (22), nebot je u nich hypofosfatemie častá. Př́iznaky hypokalemie i hyponatremie lze zaměnit za depresi i úzkostné poruchy v důsledku podobné symptomatiky (25). Hypernatremie se může vyznačovat slabostí, apatií a depresí. Při vyšším stupni hypernatremie bývá prítomno delirium s častými zrakovými iluzemi a halucinacemi.
U dětí se hypernatremie projeví spíše podrážděností a neklidem. Hyponatremie a hypernatremie jsou spojeny s dalšími somatickými komplikacemi a s nimi souvisejícími změnami duševního stavu (např. centrální pontinní myelinolýza).

\section{Kardiovaskulární poruchy}

Srdeční selhání vede k úzkostným poruchám. Při zhoršení srdečního selhání v noci může docházet k poruchám spánku, neklidu a úzkosti, které Ize zaměnit za symptomy depresivní poruchy. Mohou být př́tomny i další přiznaky deprese, jako je slabost, únava, nechutenství a úbytek váhy (25). Při větší závažnosti srdečního selhání se objevují symptomy demence, deliria nebo obou.

Palpitace jsou způsobeny řadou kardiovaskulárních poruch (angina pectoris, arytmie) a mohou vyvolávat úzkostné symptomy. U infarktu myokardu a prolapsu mitrální chlopně bývají prítomné úzkostné poruchy, zejména panická porucha (25).

Léky na léčbu kardiovaskulárních poruch mohou vyvolat psychiatrická onemocnění. Digoxin mưže vést k depresi, deliriu, poruchám spánku, halucinacím a bludům. Podávání lidokainu může vést k deliriu a depresi, propranolol může vyvolat depresi, methyldopa způsobuje depresi, delirium a poruchy sexuálních funkcí a klonidin může vést k depresi a reverzibilní demenci (25).

\section{Respirační poruchy}

Mírná hypoxie způsobuje úzkost a neklid. Těžší hypoxie vede k agitovanému deliriu. U pacientů s astmatem jsou časté úzkostné a depresivní poruchy. Při astmatickém záchvatu je prrítomna úzkost, neklid a dušnost. 
K dalším symptomům doprovázející astmatický záchvat patří únava a slabost. Závažnější forma astmatického záchvatu může vést k deliriu.

Plicní embolie může způsobit úzkost a neklid (25). Mohou se objevit panické ataky a hyperventilace. Závažná plicní embolie vede k deliriu a ke smrti.

Theofylin a aminofylin mohou vést k závratím, úzkosti, neklidu a insomnii. Obě látky rovněž mohou vést u pacientů, kteří podstupují elektrokonvulzivní terapii, k protrahovaným záchvatům a zvýšenému riziku rozvoje status epilepticus (26).

\section{Hepatální a pankreatické poruchy}

Hepatální encefalopatie se může projevovat euforií, hypománií či mánií, občas i depresí (25). V počátečních stadiích nemusí být symptomy deliria přitomny a onemocnění lze zaměnit za funkční psychiatrické onemocnění. Portosystémová encefalopatie se může manifestovat mánií, depresí, úzkostnými stavy a změnami osobnosti. Posthepatitický syndrom je soubor přiznaků, které se mohou objevit u pacientů po proběhlé virové hepatitidě. Mưže se projevovat slabostí, únavou, nechutenstvím, depresí, úzkostí. Syndrom se spontánně upraví, léčba je symptomatická. Syndrom je třeba diferenciálně diagnosticky odlišit od chronické hepatitidy B a C. Wilsonova choroba je vzácné dědičné onemocnění, které se může projevit hepatální poruchou, neurologickými a psychickými přiznaky. Hepatální porucha je přítomna vždy, ale často bývá asymptomatická. Psychiatrické symptomy, které mohou předcházet hepatální a neurologické projevy, jsou př́tomny u 1/3 pacientů s Wilsonovou chorobou a zahrnují osobnostní změny s dezinhibovaným chováním a emoční labilitou, poruchy pozornosti a hyperaktivity, které Ize u dětí a adolescentů zaměnit za ADHD nebo za poruchy chování, dále psychózu s halucinacemi a bludy, kognitivní poruchu, úzkostné poruchy včetně obsedantně kompulzivní poruchy a depresi $(23,27)$. Z neurologických symptomů mohou být prítomny cefalgie charakteru migrén, ataxie, parkinsonský syndrom, dystonie, pseudobulbární paralýza, chorea a epileptické záchvaty.

Akutní pankreatitis se může projevovat akutní psychotickou symptomatikou připomínající toxickou psychózu včetně agitovanosti, paranoidní bludné produkce a sluchových halucinací (25).

\section{Vitaminové poruchy}

Wernickeova encefalopatie vzniká následkem akutního deficitu thiaminu, může napodobovat depresi i demenci a bývá komorbidní s dalšími poruchami. Protože se často vyskytuje u alkoholiků, mưže být léčba zaměřena na delirium $v$ důsledku odnětí alkoholu a deficit thiaminu je opomenut.

Nemoc Marchiafava-Bignami je onemocnění charakterizované demyelinizací a nekrózou corpus callosum. Etiologicky se předpokládá deficit určitých vitaminů v kombinaci s toxickým účinkem alkoholu u disponovaných jedinců. Psychiatrická symptomatika může být zaměněna za depresi, ale i za Wernickeovu encefalopatii, nebot' obě onemocnění se vyskytují u alkoholiků a obě mohou mít podobný obraz magnetické rezonance mozku (23).

Chronická hypervitaminóza A se projevuje nespecifickými symptomy, jako je slabost, únava, nechutenství, bolest hlavy, poruchy spánku, deprese a mưže být zaměněna za funkční psychiatrické onemocnění (25). Deficit vitaminu D se projevuje úzkostnými symptomy, depresí a podrážděností. U dětí mohou být př́tomny noční děsy a záchvaty vzteku, proto je třeba 
deficit vitaminu $D$ diferenciálně diagnosticky zvažovat při diagnostice ADHD a poruch chování (22).

Deficit vitaminu B12 může vést k depresi, mánii, deliriu nebo změnám osobnosti (23). Psychóza je vzácným projevem deficitu vitaminu B12 (28).

\section{Infekční onemocnění}

Z infekčních onemocnění mohou být diagnosticky problematické lymeská borrelióza a neurosyfilis. Obě se mohou projevovat demencí, psychotickou a afektivní symptomatikou. Diagnostika obou je zatížena falešně pozitivními výsledky laboratorních vyšetření a u obou se psychiatrická symptomatika objevuje až po delší době prítomnosti infekce v organizmu (23).

\section{Autoimunní onemocnění}

Systémový lupus erytematodes (SLE) se může projevovat nejčastěji depresí a kognitivním deficitem, který bývá zpravidla mírný, vzácněji mánií a psychózou. Úzkostné symptomy a poruchy spánku jsou časté (22). Diferenciálně diagnosticky je třeba zvažovat uremii, kde může být podobná psychiatrická symptomatika, a léčbu kortikosteroidy, která se mưže projevovat podobnými psychiatrickými symptomy jako SLE (23). Léčba kortikosteroidy a imunosupresivy vede ke zvýšenému riziku oportunní infekce CNS a rozvoji deliria.

Kognitivní poruchy jsou prítomny u 40-65\% pacientů s roztroušenou sklerózou (RS) a ve vzácných prípadech mohou být jediným projevem onemocnění. Deprese bývá prítomna až u 50\% pacientů s RS. K dalším psychiatrickým projevům patří mánie, změny osobnosti a vzácně psychóza, která může být hlavním projevem onemocnění s prítomností nevýrazné neurologické symptomatiky (29). Psychotické symptomy se podobají schizofrenii, nicméně jsou často prítomny expanzivní bludy a neurologická symptomatika (např. parestezie) je včleněna do bludného systému. Bipolární porucha je u pacientů s RS dvakrát častější než u běžné populace (29).

Limbická encefalitis je onemocnění, jehož nejčastější prríčina spočívá v tom, že nádorové protilátky zkříženě reagují s rưznými strukturami CNS. Proto je u těchto pacientů vždy nutné pátrat po tumoru. Epileptické záchvaty jsou často př́tomny. Z psychiatrických projevů je nejčastější delirium, ale mohou být prítomny afektivní poruchy, změny osobnosti, katatonie, amnestický syndrom a psychóza $(28,30)$.

Sarkoidóza je charakterizována prítomností sarkoidových granulomů v různých orgánech. CNS je zasažena u $5 \%$ pacientů se sarkoidózou (31). Při centrálním postižení je prítomen kognitivní deficit až u 50\% pacientů. Může se objevit apatie, podrážděnost a neklid. Mohou být prítomny změny osobnosti a psychotické symptomy s halucinacemi a bludy, které Ize zaměnit za schizofrenii $(23,32)$. Postižení hypotalamu může vést k somnolenci, hypertermii či diabetu insipidu (22).

\section{Spánkové poruchy}

Obstrukční spánková apnoe může vést k depresi, často je přítomen kognitivní deficit, úzkostné stavy, delirium a u dětí ji lze zaměnit za ADHD $(23,33)$. Etiologicky je nutné u dětí zvažovat kromě dalších prríčin zejména zvětšení tonzil a rovněž Downův syndrom. Obstrukční spánková apnoe může způsobovat srdeční arytmie včetně fibrilace síní, systolickou hypertenzi, plicní hypertenzi a epilepsii. Proto je třeba zvažovat psychiatrickou symptomatiku v kontextu těchto poruch včetně rizika cévních mozkových příhod či krvácení do CNS a s tím souvisejícími symptomy. 
Narkolepsie je vzácné onemocnění charakterizované epizodami záchvatu spánku během dne a kataplexií, tj. ztrátou tonu kosterního svalstva. Ta může být celková, nebo omezená jen na určité skupiny svalů. Mưže docházet k úrazům. Dále se onemocnění projevuje spánkovou obrnou a hypnagogickými a hypnopompními halucinacemi. U 60-70\% pacientů jsou rovněž prítomny poruchy spánku charakterizované častým nočním probouzením a obtížemi s usínáním. Přes 50 \% pacientů s narkolepsií má depresivní poruchu (34). Úzkostné poruchy jsou rovněž časté. Panické ataky jsou zejména vyvolány děsivými prožitky během hypnagogických a hypnopompních halucinací. Bývají přitomny specifické fobie (např. strach z pádu, strach z nakažlivé nemoci). Hypnagogické a hypnopompní halucinace je třeba odlišit od psychotického onemocnění. Narkoleptické halucinace jsou živé, většinou zrakové, mohou být i sluchové a taktilní. Typický je pocit prítomnosti někoho nebo něčeho v místnosti. Občas se tyto halucinace mohou objevit i během dne, kdy narušují běžné denní aktivity. Spánková obrna je přechodná neschopnost pohybu a řeči během přechodu z bdění do spánku nebo naopak. Může vyvolávat masivní úzkost, protože je často doprovázena pocitem neschopnosti dýchat. Rovněž se někdy mohou u pacientů s narkolepsií objevit epizody amnézie s př́tomností automatického chování (22). Diferenciálně diagnosticky je třeba zvažovat obstrukční spánkovou apnoi i proto, že u narkolepsie může dojít k nárůstu hmotnosti a obě onemocnění mohou být přitomna zároveň, dále tumory, hypotyreózu, hypoglykemii, epilepsii, myastenii gravis, roztroušenou sklerózu a Klein-Levinưv syndrom. Z psychiatrických onemocnění kromě psychózy a deliria je třeba zvažovat disociativní poruchy a ADHD. Stimulancia, která se používají na léčbu narkolepsie, mohou vést k epileptickým záchvatům, ke kardiálním poruchám a k deliriu. Stejné poruchy vyvolávají tricyklická antidepresiva, která se používají k léčbě kataplexie, spánkové obrny a hypnagogických a hypnopompních halucinací (25).

\section{Epilepsie}

Epilepsie, zejména dlouhotrvající, mưže vést k interiktální psychóze napodobující schizofrenii, k interiktální depresivní poruše, k postiktální psychóze s výraznou agitovaností a neklidem, k postiktálnímu deliriu nebo k úzkostným poruchám (22). Nejčastější psychiatrické komorbidity u pacientů s epilepsií jsou deprese, bipolární porucha a ADHD (35).

Nekonvulzivní status epilepticus může napodobit řadu duševních poruch. Mohou být přítomny poruchy myšlení, vnímání, emocí i psychomotoriky. Proto zejména u náhle vzniklých duševních symptomů je třeba vyloučit epileptickou etiologii. Epilepsii je nutno odlišit od psychogenních neepileptických záchvatů (PNES). Odlišení bývá obtížné zejména u pacientů s komorbidní epilepsií. Video-EEG může pomoci k odlišení, ale záchvat nemusí být při monitoraci zachycen. Přibližně $25 \%$ pacientů léčených pro farmakorezistentní epilepsii má PNES $(22,36)$. Diferenciálně diagnosticky je třeba u PNES vyloučit epilepsii, endokrinní přičiny, kardiovaskulární př́činy (arytmie, plicní embolie), migrénu, cerebrální příčiny (cévní mozková porucha, krvácení) a poruchy spánku (narkolepsie).

\section{Endokrinní poruchy}

Hypoparatyreóza se může projevovat zejména kognitivním deficitem, rovněž depresí s únavou a úzkostnými symptomy. Vzácněji se mohou objevit psychotické př́znaky, a to zejména u sekundární hypoparatyreózy. Nejčastějším projevem hyperparatyreózy je deprese s apatií, únavou a nedostatkem inciativy. Někdy se může objevit úzkost a podrážděnost. 
Psychotické symptomy jsou vzácné a mohou se objevit pod obrazem paranoidní psychózy s halucinacemi, paranoidními bludy a agresivním chováním (28).

Hypertyreóza se může projevovat depresí, úzkostnými stavy, manickou anebo psychotickou symptomatikou. Hypotyreóza se může manifestovat kognitivními poruchami, poruchami pozornosti, depresí často doprovázenou úzkostnými stavy a vzácně psychózou s paranoidními bludy a sluchovými halucinacemi (23).

Cushingův syndrom a Addisonova choroba se mohou projevovat zejména depresivním syndromem, v závažnějších prípadech psychotickou symptomatikou a katatonním syndromem. U Addisonovy choroby je třeba diferenciálně diagnosticky zvažovat kromě autoimunitních a infekčních př́čin zejména tumory, krvácení do CNS a adrenoleukodystrofii. Dětská forma adrenoleukodystrofie se může projevovat kromě projevů adrenokortikální insuficience rovněž symptomy připomínajícími ADHD a u adultní formy mohou být prítomny manické symptomy a demence (23). U Cushingova syndromu je třeba diferenciálně diagnosticky zvažovat zejména tumory CNS a nadledvin a v kontextu těchto chorob zvažovat psychiatrickou symptomatiku (37).

Hypoglykemie, zejména subakutní, a chronický neuroglykopenický syndrom se mohou projevovat dezinhibovaným chováním připomínajícím intoxikaci alkoholem, kognitivním deficitem, který může imponovat jako demence, a paranoiditou, u které může dojít k záměně za psychózu. U déle trvající hypoglykemie je třeba vždy zvažovat kromě špatně nastavené antidiabetické léčby zejména inzulinom (22).

Počáteční symptomy uremie se mohou podobat depresi se slabostí, únavou a insomnií. Výrazná je porucha pozornosti (25). Mohou se objevit poruchy paměti, zhoršení úsudku. Při pomalém rozvoji uremie mohou být duševní změny její první manifestací (22). Vzácně se uremie může manifestovat mánií (23). Pokud je prítomno delirium, jsou často prítomny zrakové halucinace.

Diabetes insipidus, který vzniká v důsledku nedostatečné produkce antidiuretického hormonu (ADH), může vést k hypernatremii, a s tím souvisejícím psychiatrickým symptomům. Důležité je odlišit diabetes insipidus od primární polydipsie, která je př́tomna u řady duševních poruch (mánie, schizofrenie, poruchy osobnosti). Pokud je primární polydipsie léčena desmopresinem (syntetický analog ADH), může dojít k intoxikaci vodou. U každého psychotického pacienta s poruchami vědomí a epileptickými záchvaty je třeba diferenciálně diagnosticky zvažovat primární polydipsii.

\section{Trauma}

Traumatické poškození mozku se projevuje řadou psychiatrických symptomů, které závisí na rozsahu a umístění hematomu. Po akutní fázi, kdy je přítomno delirium, které je typicky agitované s výraznými halucinacemi a bludy, se může objevit rozmanitá psychiatrická symptomatika. Kognitivní deficit se postupně upravuje. Agitovanost je častá v následujících měsících po úraze a rovněž se postupně upravuje. Poúrazové změny osobnosti jsou časté, ale je třeba vzít v úvahu premorbidní osobnost (zejména disociální a hraniční) (23). Deprese se objeví až u 50 \% pacientů s traumatickým postižením mozku. Může spontánně odeznít, nebo přetrvávat (38). Depresi je nutné odlišit od emoční inkontinence, která je po traumatickém poškození mozku častá. K zjištění etiologie deprese je třeba zjistit, zda pacient netrpěl depresivní poruchou již před úrazem (23). Mánie je relativně vzácná a častější při postižení temporálních lalo- 
ků (23). Mánii je třeba odlišit od dezinhibovaného chování u syndromu frontálního laloku, mozečkového kognitivně-afektivního syndromu, od Klüver-Bucyho syndromu a premorbidní diagnózy bipolární poruchy. Trauma může vést $k$ sekundárnímu ADHD nebo zhoršit již existující symptomy ADHD (39). Na traumatickou příčinu zhoršení symptomatologie ADHD je třeba myslet i proto, že u dětí s ADHD je trojnásobně vyšší riziko poranění CNS ve srovnání s dětmi bez ADHD.

\section{Cévní mozkové příhody}

Cévní mozková príhoda vede k demenci a deliriu. Přibližně u 40\% pacientů se týdny až měsíce po mozkové príhodě rozvine depresivní porucha (23). Úzkostné poruchy se objeví u približně 20\% pacientů po cévní mozkové př́hodě, a to zejména při postižení pravé hemisféry. K dalším symptomům patři emoční inkontinence, syndrom frontálního laloku, mánie (při postižení frontálního, temporálního laloku, thalamu, mesencefala a nucleus caudatus) a psychóza (zejména při postižení frontálního, temporálního laloku a thalamu) (23).

\section{Nádory}

Nádory CNS se mohou projevovat př́znaky demence (zejména ve frontálním laloku, temporálním laloku a corpus callosum), deprese (umístění nádoru ve frontálním a temporálním laloku), mánie (temporální lalok, frontální lalok, thalamus a hypotalamus) a psychózy (umístění ve frontálním laloku, temporálním laloku a corpus callosum). Rovněž mohou být přitomny změny osobnosti (zejména v oblasti frontálního laloku, temporálního laloku a corpus callosum) (22). U pacientů s náhle vzniklou změnou duševního stavu, zejména ve vyšším věku spolu s prítomností bolesti hlavy, je třeba vždy zvažovat nádorovou příčinu. Nádory se rovněž mohou projevovat řadou endokrinních př́znaků (diabetes insipidus, hyperfagie, nechutenství, insomnie), které mohou vést k dalším metabolickým poruchám.

\section{Katatonie}

Organická katatonní porucha mưže být zpưsobena řadou somatických stavů, jako jsou endokrinopatie (feochromocytom, hypoparatyreóza, thyreotoxikóza), infekce (lymeská borrelióza), tumory (zejména frontálního, temporálního laloku a corpus callosum) (22), cévní mozková príhoda, traumatické poranění mozku (subdurální frontoparietální hematom), epilepsie (nekonvulzivní status epilepticus, interiktální psychóza), autoimunní onemocnění (systémový lupus erytematodes), dědičná onemocnění (Wilsonova choroba, Tay-Sachsova choroba), dále popáleniny, SIADH syndrom, deficit vitaminu $\mathrm{B}_{12^{\prime}}$ Cushingưv syndrom, Addisonova choroba (40) a centrální pontinní myelinolýza (41). Katatonní symptomatiku mohou vyvolat antipsychotika, syndrom z odnětí benzodiazepinů, náhlé vysazení dopaminergních látek, stimulancia, opiáty, rovněž i disulfiram a ciprofloxacin (23).

Neproduktivní katatonní poruchu je nutné odlišit od kómatu, hypoaktivního deliria, abulie, psychózy a depresivní poruchy. Produktivní katatonii je třeba odlišit od mánie, protože se může objevit až v $15 \%$ manických epizod u pacientů s bipolární poruchou, od schizofrenie (10\% pacientů s katatonií splňuje kritéria pro schizofrenii) (40) a od hyperaktivního deliria. Opakující se povaha stereotypií, grimasování a manýrování mohou připomínat obsedantně kompulzivní poruchu či Tourettův syndrom. Z dalších významných chorob je z diferenciálně diagnostického hlediska důležité odlišení Parkinsonovy choroby, maligní hypertermie, stiff-person syndromu a locked-in syndromu (40). 


\section{Další poruchy}

Osmotický demyelinizační syndrom, který zahrnuje centrální pontinní a extrapontinní myelinolýzu, je závažné onemocnění, které vzniká v důsledku řady poruch, ale nejčastěji při rychlé úpravě hyponatremie. Projevuje se neurologickou a psychiatrickou symptomatikou. Přibližně $25 \%$ pacientů má pouze psychiatrické symptomy (42). Onemocnění se mưže projevovat osobnostními změnami, depresí, úzkostnými příznaky a agitovaností s psychotickými symptomy (41). Nejrizikovější skupinou pacientů jsou pacienti s malnutricí, chronickou závislostí na alkoholu a pacienti po transplantaci jater (23). Diferenciálně diagnosticky je třeba odlišit zejména delirium po odnětí alkoholu a hepatální encefalopatii.

Mozečkový kognitivně-afektivní syndrom vzniká v důsledku řady afekcí postihující mozeček. V popředí je změna osobnosti charakterizovaná dezinhibovaným chováním, impulzivitou nebo naopak oploštěním afektivity, dále je prítomna porucha pozornosti, řečových a exekutivních funkcí a kromě záměny za $A D H D$, která je zvažována spíše u dětí, může dojít k záměně za depresi, mánii, poruchu osobnosti a demenci (43).

\section{Odmítání podrobit se léčbě}

Za normálních okolností je třeba respektovat přání pacienta odmítnout léčbu. U závažných duševních poruch, jako je např́klad schizofrenie nebo demence, může být schopnost úsudku výrazně narušena. U schizofrenie může být přítomno bludné přesvědčení, že okolí chce pacientovi ubližit, a to se mưže vztahovat i na léčbu.

Zhodnotit schopnost pacienta posoudit svůj zdravotní stav je důležité zejména, pokud pacient odmítá život zachraňující výkony či léčbu (napřiklad krevní transfuzi nebo operaci nádoru), odmítá uživat léky, nebo když pacient vyžaduje, aby ošetřující personál ukončil jeho život $(44,45)$. Problém nastává u hraničních stavů, napřiklad u deprese bez psychotických symptomů nebo u lehkého stupně demence. Je odmítání léčby v důsledku snahy zemřít, nebo pacientovi napríklad nevyhovuje postup navržený lékařem a v důsledku omezené schopnosti komunikace není schopen se adekvátně vyjádřit? Odmítání mưže být i v důsledku nepochopení sdělované informace, což bývá běžné u pacientů s demencí a u pacientů s nasedajícím delirantním stavem. Nemusí se jednat prímo o odmítání, ale o výraznou nerozhodnost. Suicidalita nemusí být spojena se zhoršenou schopností posoudit situaci a rozhodnout se neprǐimout léčbu, pokud vychází ze zdravého uvažování a chápání situace, jako např́klad u terminálně nemocných pacientů. Psychiatr je v těchto prípadech volán, aby zhodnotil duševní stav pacienta a rozhodnul, jestli je pacient schopen odmítnout léčbu.

\section{Sebevražedné a automutilační pokusy}

Jedním z nejčastějších důvodů psychiatrického konzilia na JIP je sebevražedný pokus (46). Zde je psychiatr žádán, aby rozhodl, zda je možné propuštění pacienta, či zda je vhodná psychiatrická intervence.

K predisponujícím rizikovým faktorům suicidia patří vyšší věk, mužské pohlaví, nízký socioekonomický stav, nízké vzdělání, chudoba, rodinný stav (svobodní či rozvedení), rodinné prostředí (zejména problematické rodinné prostředí s hádkami, týráním, sexuálním zneužíváním), zaměstnání (např. lékaři, manažeři (47)), homosexualita, psychiatrické onemocnění, somatické onemocnění, sebevražedný pokus v anamnéze, kontakt s lidmi, kteří se pokusili o suicidium, abúzus alkoholu či jiných návykových látek (48).

K precipitujícím rizikovým faktorům patří nepříznivé životní události (napřr. rozvod, rozchod, úmrtí blízké osoby, zjištěná diagnóza závažného 
onemocnění), intoxikace alkoholem či jinými návykovými látkami (46). Podle K. Skegga není sebevražedný pokus nemoc, ale chování. „Proto další postup velmi závisí na základním problému, který může sahat od psychózy s intenzivními suicidálními myšlenkami vyžadující hospitalizaci k impulzivním činům na stresovou událost, která se zvládne s podporou rodiny" (str. 1478-1479)(46). Impulzivní činy jsou charakterizovány nedostatečnou rozvahou, jsou vedené z náhlého popudu, nejsou dostatečně promyšlené, jsou nepřiměřeně rizikové a mnohdy vedou k nežádoucím následkům. Impulzivní chování je charakteristické pro hraniční a disociální poruchu osobnosti a pro ADHD. Impulzivní činy jsou často spojené se sebevražedným a násilným chováním (49).

U některých pacientů po suicidálním pokusu je potřeba hospitalizace na psychiatrii, u jiných je hospitalizace naopak kontraproduktivní. J. Paris (50) tvrdí, že hospitalizace chronicky suicidálního pacienta s hraniční poruchou osobnosti vede k tomu, že je tento pacient přijat do prostředí, které posiluje právě to chování, které se psychoterapie snaží změnit. To vede k opakovaným hospitalizacím kvưli suicidálním pokusům (chronicky suicidální chování popisuje Paris jako zpưsob chování, kterým pacienti s hraniční poruchou osobnosti sdělují úzkost). Přičina může být v tom, že hospitalizace poskytuje sociální zázemí, které pacientovi extramurálně chybí. Dalším důvodem může být to, že když se pacient poraní, získá více péče od ošetřujícího personálu, čímž se posiluje jeho patologické chování.

\section{Zhodnocení vhodnosti léčby pacienta}

Po psychiatrovi se může požadovat, aby zhodnotil, zda je pacient schopen pochopit a dát validní souhlas s určitým výkonem či postupem, např. transplantace, dárcovstvím orgánu, žádost o kosmetickou chirurgii. Taktéž se po psychiatrovi může žádat, aby rozhodl, zda je pacient vhodný k danému výkonu (např. transplantace jater u pacienta se závislostí na alkoholu) či zda je schopen dodržovat pravidla v období po výkonu (např. setrvání v lůžku, nenašlapování na nohu u fraktury apod.). Rovněž může být po psychiatrovi požadováno, aby zhodnotil riziko dekompenzace psychického stavu v souvislosti s výkonem a období po něm.

Reaktivní stavy, úzkostné a depresivní poruchy

U somaticky nemocných pacientů jsou často přitomny stresové události. Mưže se jednat o poranění nebo o akutní dekompenzaci somatického onemocnění.

Akutní stresové reakce jsou běžné po závažných událostech, jako jsou automobilové nehody. Pacienti mohou být úzkostní, neklidní, podráždění. Mohou popírat skutečnost nebo následky toho, co se jim stalo (51).

Poruchy přizpůsobení jsou přechodné reakce na stresovou událost a obvykle se manifestují jako depresivní nebo úzkostné poruchy. Mohou se rovněž projevovat poruchami chování a špatnou compliance při léčbě. Závažnost symptomů často kolísá spolu s kolísáním závažnosti somatického stavu a úspěšností jeho léčby. U části pacientů s poruchou přizpůsobení se rozvine trvalé duševní onemocnění, obvykle deprese.

Posttraumatická stresová porucha je dlouhodobá emoční reakce na události v minulosti, které byly vnímány jako život ohrožující. Počátek přiznaků může být týdny i měsíce po kritické události. Typické je znovuproživání stresující události v predstavách, myšlenkách či v tělesných přiznacích jako tzv. flashbacky. Dále jsou prítomny noční můry, přetrvávající úzkost, poruchy spánku a snaha vyhnout se situacím, které kritickou udá- 
lost připomínají. Často se vyskytuje u účastníků dopravních nehod a jako komplikace závažného somatického stavu a jeho léčby (52).

Panická porucha je častou prríčinou návštěvy nemocnice, ale nejednou zůstává nerozpoznána (53). Bývá obvyklou príčinou závratí, parestezií, dušnosti, palpitací a bolestí na hrudi. Generalizovaná úzkostná porucha se může projevovat únavou, povšechnými bolestmi nebo obavami z nemoci. Její prítomnost často přispívá k funkčním somatickým symptomům a nadměrnému využívání lékařských služeb (9). Specifické fobie mohou bránit diagnostice a léčbě pacienta. Zejména strach z krve a injekčních jehel představují závažný problém na chirurgických a interních odděleních. Klaustrofobie může bránit provedení CT či MR vyšetření.

Deprese je častá u pacientů s tělesným onemocněním, u nichž se může vyskytovat v komorbiditě, tj. nezávisle na somatické diagnóze. Mưže být rovněž považována za důsledek tělesného onemocnění, pak by měla být diagnostikována jako organická depresivní porucha. Ale přesné oddělení těchto dvou poruch v řadě prípadů není možné. Např. deprese po cévní mozkové př́hodě může být důsledkem vlastního somatického onemocnění, ale i jako psychický stresor. Kromě toho diagnóza organické deprese může vést k opominutí psychogenního a sociálního aspektu etiologie a léčby. Diagnostika deprese je u těchto pacientů důležitá, protože zvyšuje jejich morbiditu a mortalitu.

\section{Zneuživání psychoaktivních látek}

Alkohol je nejčastější zneužívanou látkou vyskytující se u pacientů na somatických odděleních, a to zejména na traumatologických JIP $(54,55)$. K dalším zneužívaným látkám patří zejména opiáty, benzodiazepiny a stimulancia. Pacient se mưže projevovat symptomy intoxikace, syndromem z odnětí nebo somatickými komplikacemi spojenými s užíváním těchto látek (např. jaterní encefalopatie). Pacienti s abúzem drog se mohou projevovat agitovaným chováním, agresí, mohou požadovat drogu nebo její ekvivalent, nebo mohou agravovat své somatické onemocnění ve snaze získat větší množství léků proti bolesti. Často jsou to pacienti s kriminální minulostí (56). Po psychiatrovi se požaduje, aby akutní stav zvládl a doporučil další postup v léčbě. Diferenciálně diagnosticky je třeba vždy zvažovat schizofrenii, bipolární poruchu či organicky podmíněné psychiatrické onemocnění.

\section{Psychotické poruchy}

Schizofrenie a další psychotické poruchy jsou na somatických odděleních relativně vzácné. Občas se ale mohou objevit pacienti se zvláštními symptomy nebo stižnostmi. Vždy je třeba vyloučit somatickou etiologii potíží, i kdyby se jednalo o velmi bizarní př́znaky (4). Zjištění anamnézy od př́buzných či od praktického lékaře pomưže zjistit, jestli pacient netrpěl duševním onemocněním ještě před hospitalizací a usnadní psychiatrickou intervenci.

\section{Príčiny psychiatrické poruchy}

U pacienta se somatickou chorobou se mưže rozvinout duševní onemocnění z těchto př́íin:

- komorbidita (somatické a psychiatrické onemocnění spolu nesouvisí)

- společná přičina (stresové události mohou ovlivnit jak somatický, tak duševní stav - např́klad může dojít ke vzniku jak deprese, tak cévní mozkové príhody)

- duševní onemocnění může vyvolat somatický stav (suicidální pokus, abúzus psychoaktivních látek) 
• tělesné onemocnění nebo jeho léčba může vyvolat duševní onemocnění, a to bud' prímou organickou príŕinou (např. krvácení do mozku), nebo jako psychický stresor.

Nezáleží jen na objektivní povaze nemoci, ale rovněž na jejím významu pro pacienta. Když se napríklad pacient dozví, že má maligní tumor, může být depresivní, pokud je přesvědčen, že je onemocnění nevyléčitelné (4), nebo může jít o psychickou reakci na sociální důsledky somatického onemocnění - napřiklad ztráta zaměstnání nebo sociální stigma spojené s určitými nemocemi (syfilis, AIDS).

\section{Diagnostika a léčba}

Při vyšetřování pacienta psychiatrem je vhodné nalézt klidné a nerušené místo. Informace je třeba získat nejen od pacienta, ale i od ošetřujicíího personálu, a pokud lze, tak i od rodinných príslušníků k doplnění objektivní anamnézy. Někdy pacienti mohou zcela odmítat psychiatrické vyšetření. Pak je třeba pečlivě vysvětlit dưvody vyšetření a zmírnit jakékoliv obavy ze somatického onemocnění, léčby a z možné stigmatizace. Duševní onemocnění je třeba hodnotit jako př́mý důsledek somatického stavu i jako psychický stresor. Psychiatrická diagnóza nemusí být vždy jednoznačná. Při neúplně vyjádřené symptomatice, která je ovlivněna somatickým stavem, mưže být rozdíl napríklad mezi organickou depresivní poruchou, deliriem a poruchou přizpůsobení velmi úzký, a to zejména v prípadech, kdy je kontakt s pacientem omezen. Príčiny duševního stavu Ize rozdělit na

- biologické (somatické onemocnění)

- duševní (např. nálada, kognitivní funkce)

- sociální (např. interpersonální vztahy, zaměstnání) (2).
Podle podílu jednotlivých prǐčin psychiatr diagnostikuje onemocnění s doporučením intervence (léčba základního somatického onemocnění, léčba duševního onemocnění, podpưrná či dlouhodobá psychoterapie, sociální intervence) (4). Když psychiatr diagnostikuje duševní onemocnění, kterým Ize vysvětlit somatický stav (např. deprese), mohou somatičtí lékaři přestat dále vyšetřovat pacienta či bagatelizovat somatické onemocnění. Pacient se nemusí vůbec dostat do kontaktu s psychiatrem, protože somatičtí lékaři se mohou domnívat, že je třeba léčit akutní somatické onemocnění a duševní onemocnění pro ně není důležité. Pacient rovněž nemusí být schopen sdělit své psychické potíže, at už $\checkmark$ důsledku omezené schopnosti komunikace, nebo proto, že je mu nepř́ijemné o nich mluvit (4). Pokud je zahájena psychiatrická léčba, je třeba sledovat psychiatrické symptomy, jejich dynamiku a nežádoucí účinky na léčbu. Léčba může být neúčinná kvưli nedostatečnému dávkování nebo nežádoucím účinkům léků a pacient pak může odmítat medikaci. Do dokumentace je třeba podrobně vysvětlit diagnózu s doporučením dalšího postupu léčby včetně další kontroly duševního stavu pacienta. Pouze krátká zmínka o léčbě do konziliárního vyšetření může vést k zanedbání doporučené léčby (57). Při potřebě psychoterapie musí konziliární psychiatr vzít v úvahu dostupnost zkušeného terapeuta. U psychofarmak je nezbytné zjistit, zda je daný lék dostupný. Pokud tomu tak není, může dojít k prodlení zahájení léčby.

\section{Závěr}

Somatická medicína a psychiatrie se vzájemně prolínají a nezvažování duševního rozměru u somatických pacientư může vést k zvýšení morbidity a mortality a celkově zhoršit průběh somatického onemocnění, at už se jedná 
o hospitalizované nebo ambulantní pacienty. Naopak opakované vyšetřování pacienta s tělesnými symptomy na somatickém oddělení může vést

\section{LITERATURA}

1. Borrell-Carrió F, Suchman AL, Epstein RM. The biopsychosocial model 25 years later: principles, practice, and scientific inquiry. The Annals of Family Medicine, 2004; 2.6: 576-582.

2. Sharpe M, Walker J. Symptoms: A new approach. Psychiatry, 2009; 8.5: 146-148.

3. Roca M, Gili M, Garcia-Garcia M, Salva J, Vives M, Campayo JG, Comas A. Prevalence and comorbidity of common mental disorders in primary care. Journal of affective disorders, 2009; 119.1: 52-58.

4. Johnstone, Eve C, David Cunningham Owens, and Stephen M. Lawrie. Companion to psychiatric studies. Elsevier Health Sciences, 2010.

5. De Gucht V, Fischler B. Somatization: a critical review of conceptual and methodological issues. Psychosomatics, 2002; 43.1: 1-9.

6. Löwe B, Spitzer RL, Williams JBW, Mussell M, Schellberg D, Kroenke K. Depression, anxiety and somatization in primary care: syndrome overlap and functional impairment. General hospital psychiatry, 2008; 30.3: 191-199.

7. Longstreth GF, Thompson WG, Chey WD, Houghton LA, Mearin F, Spiller RC. Functional bowel disorders. Gastroenterology 2006; 130.5: 1480-1491.

8. Whitehead WE, Palsson O, Jones KR. Systematic review of the comorbidity of irritable bowel syndrome with other disorders: what are the causes and implications? Gastroenterology, 2002; 122.4: 1140-1156.

9. Roy-Byrne PP, Davidson KW, Kessler RC, Asmundson GJG, Goodwin RD, Kubzansky L, Lydiard RB, Massie MJ, Katon W, Laden SK, Stein MB. Anxiety disorders and comorbid medical illness. General hospital psychiatry, 2008; 30.3: 208-225.

10. Albert CM, Chae CU, Rexrode KM, Manson JE, Kawachi I. Phobic anxiety and risk of COronary heart disease and sudden cardiac death among women. Circulation, 2005; 111.4: 480-487.

11. Arnow BA, Hunkeler EM, Blasey CM, Lee J, Constantino MJ, Fireman B, Kraemer HC, Dea R, Robinson R, Hayward C. Comorbid depression, chronic pain, and disability in primary care. Psychosom Med, 2006; 68.2: 262-268.

12. Means-Christensen AJ, Roy-Byrne PP, Sherbourne CD, Craske MG, Stein MB. Relationships among pain, anxiety, and depression in primary care. Depress Anxiety, 2008; 25.7: 593-600. 13. Hocaoglu C, Gulec MY, Durmus I. Psychiatric comorbidity in patients with chest pain without a cardiac etiology. The Israel journal of psychiatry and related sciences, 2008; 45.1: 49 k nákladnější léčbě a v řadě případů mưže stačit vyšetření a přiměřená léčba psychiatrem, aby došlo k výraznému zmírnění somatické symptomatiky.

14. Kirmayer LJ, Looper KJ. Abnormal illness behaviour: physiological, psychological and social dimensions of coping with distress.Current Opinion in Psychiatry, 2006; 19.1: 54-60.

15. Maldonado JR. Neuropathogenesis of delirium: review of current etiologic theories and common pathways. The American Journal of Geriatric Psychiatry, 2013; 21.12: 1190-1222.

16. Fick D, Agostini JV, Inouye SK. Delirium superimposed on dementia: a systematic review. Journal of the American Geriatrics Society, 2002; 50.10: 1723-1732.

17. McKeith I, Mintzer J, Aarsland D, Burn D, Chiu H, Cohen-Mansfield J, Dickson D, Dubois B, Duda JE, Feldman H, Gauthier S, Halliday G, Lawlor B, Lippa C, Lopez OL, Machado JC, O'Brien J, Playfer J, Reid W. Dementia with Lewy bodies. The Lancet Neurology, 2004; 3.1: 19-28. 18. Yudofsky SC, Hales RE. Essentials of Neuropsychiatry and Behavioral Neurosciences. American Psychiatric Pub, 2010.

19. Maldonado JR. Delirium in the acute care setting: characteristics, diagnosis and treatment. Critical care clinics, 2008; 24.4: 657-722.

20. Fundukian LJ, Wilson J. The Gale Encyclopedia of mental health $3^{\text {rd }}$ ed. 2012

21. Herman E, Praško J, Seifertová D (ed.). Konziliární psychiatrie. Medical Tribune, 2007.

22. David, A. Lishman's organic psychiatry: a textbook of neuropsychiatry. John Wiley and Sons, 2009.

23. Moore DP, Puri BK. Textbook of Clinical Neuropsychiatry and Behavioral Neuroscience 3E. CRC Press, 2012.

24. Hatherill S, Flisher AJ. Delirium in children and adolescents: a systematic review of the literature. Journal of psychosomatic research, 2010; 68.4: 337-344.

25. Jefferson JW. Neuropsychiatric features of medical disorders. Springer Science \& Business Media, 2012

26. Loo C, Simpson B, Macphersom R. Augmentation strategies in electroconvulsive therapy. The journal of ECT, 2010; 26.3: 202-207.

27. Ala A, Walker AP, Ashkan K, Dooley JS, Schilski ML. Wilson's disease. The Lancet, 2007; 369.9559: 397-408

28. Hyde TM, Ron MA. Schizophrenia, Third Edition, Blackwell Publishing, 2011.

29. Ghaffar O, Feinstein A. The neuropsychiatry of multiple sclerosis: a review of recent developments. Current Opinion in Psychiatry, 2007; 20.3: 278-285. 
30. Samarasekera SR, Vincent A, Welch JL, Jackson M, Nichols P, Griffiths TD. The course and outcome of acute limbic encephalitis with negative voltage-gated potassium channel antibodies. Journal of Neurology, Neurosurgery \& Psychiatry, 2006.

31. Joseph FG, Scolding NJ. Sarcoidosis of the nervous system. Practical Neurology, 2007; 7.4: 234-244

32. Green MW, Muskin PR (ed.). The Neuropsychiatry of Headache. Cambridge University Press, 2013.

33. Klykylo WM, Kay J. Clinical child psychiatry. Wiley-Blackwell, 2012.

34. Mamelak M. Narcolepsy and depression and the neurobiology of gammahydroxybutyrate. Progress in neurobiology, 2009; 89.2: 193-219.

35. Ottman R, Lipton RB, Ettinger AB, Cramer JA, Reed ML, Morrison A, Wan GJ. Comorbidities of epilepsy: results from the Epilepsy Comorbidities and Health (EPIC) survey. Epilepsia, 2011; 52.2: 308-315.

36. Kotsopoulos IAW, De Krom MCTF, Kessels FGH, Lodder J, Troost J, Twellaar M, van Merode $T$, Knottnerus AJ. The diagnosis of epileptic and non-epileptic seizures. Epilepsy research, 2003; 57.1: 59-67.

37. Longo DL, Fauci AS, Kasper DL, Hauser SL, Jameson, JL, Loscalzo J. Harrison's Principles of Internal Medicine 18th ed. McGraw-Hill Medical, 2012

38. Jorge RE, Robinson RG, Moser D, Tateno A, Crespo-Facorro B, Arndt S. Major depression following traumatic brain injury. Arch Gen Psychiatry, 2004; 61.1: 42-50.

39. Canadian Attention deficit Hyperactivity Disorder Resource Alliance (CADDRA). Canadian ADHD Practice Guidelines. 2011.

40. Fink M, Taylor MA. Catatonia: a clinician's guide to diagnosis and treatment. Cambridge University Press, 2006.

41. King JD, Rosner MH. Osmotic demyelination syndrome. The American journal of the medical sciences, 2010, 339.6: 561-567.

42. Lampl C, Yazdi K. Central pontine myelinolysis. Eur Neurol, 2002; 47.1: 3-10.

43. Schmahmann JD. Disorders of the cerebellum: ataxia, dysmetria of thought, and the cerebellar cognitive affective syndrome. The Journal of neuropsychiatry and clinical neurosciences, 2004; 16.3: 367-378.
44. Rudnick A. Depression and competence to refuse psychiatric treatment. Journal of Medical Ethics, 2002; 28.3: 151-155.

45. Banner NF. Unreasonable reasons: normative judgements in the assessment of mental capacity. Journal of evaluation in clinical practice, 2012; 18.5: 1038-1044.

46. Skegg, K. Self-harm. The Lancet, 2005; 366.9495: 1471-1483.

47. McIntosh WL, Spies E, Stone DM, Lokey CN, Trudeau AT, Bartholow B. Suicide Rates by Occupational Group - 17 States, 2012. MMWR Morb Mortal Wkly Rep 2016; 65: 641-645.

48.Valenstein $\mathrm{H}$, Cronkite RC, Moos RH, Snipes C, Timko C. Suicidal ideation in adult offspring of depressed and matched control parents: Childhood and concurrent predictors. Journal of Mental Health, 2012; 21.5: 459-468.

49. Dolan M, Fullam R. Behavioural and psychometric measures of impulsivity in a personality disordered population. Journal of Forensic Psychiatry \& Psychology, 2004; 15.3: 426-450.

50. Paris J. Chronic suicidality among patients with borderline personality disorder. Psychiatr Serv 2002; 53: 738-742.

51. Rabinowitz T, Peirson R. "Nothing is wrong, doctor": understanding and managing denial in patients with cancer. Cancer investigation, 2006; 24.1: 68-76.

52. Nickerson A, Aderka IM, Bryant RA, Hofmann SG. The role of attribution of trauma responsibility in posttraumatic stress disorder following motor vehicle accidents. Depression and anxiety, 2013; 30.5: 483-488.

53. Roy-Byrne PP, Craske MG, Stein MB. Panic disorder. The Lancet, 2006; 368.9540: 1023-1032. 54. Kriston L, Hölzel L, Weiser AK, Berner MM, Härter M. Meta-analysis: are 3 questions enough to detect unhealthy alcohol use?. Annals of internal medicine, 2008; 149.12: 879-888.

55. Neumann T, Spies C. Use of biomarkers for alcohol use disorders in clinical practice. Addiction, 2003; 98.s2: 81-91.

56. Harris A, Lurigio AJ. Mental illness and violence: A brief review of research and assessment strategies. Aggression and violent behavior, 2007; 12.5: 542-551.

57. Kathol RG, Kunkel EJS, Weiner JS, McCarron RM, Worley LLM, Yates WR, Summergrad P, Huyse FJ. Psychiatrists for medically complex patients: bringing value at the physical health and mental health/substance-use disorder interface. Psychosomatics, 2009; 50.2: 93-107. 